\title{
Improvement of growth and productivity of cotton (Gossypium hirsutum L.) through foliar applications of naphthalene acetic acid
}

\author{
Melhoria do crescimento e produtividade do algodão \\ (Gossypium hirsutum L.) através de aplicações foliares do ácido \\ naftaleno-acético
}

\author{
Shazia Parveen ${ }^{1}$; Rana Muhammad Iqbal²; Muhammad Akram³; \\ Faheem Iqbal'; Muhammad Tahir ${ }^{3}$; Muhammad Rafay ${ }^{5}$
}

\begin{abstract}
Plant growth regulators like naphthalene acetic acid (NAA) positively affect the growth and yield of crop plants. An experiment was conducted to check the foliar application of NAA on growth and yield components of cotton variety Bt.121 under field condition at research area of agriculture farm near Cholistan Institute of Desert Studies (CIDS), The Islamia University of Bahawalpur, Pakistan. The experiment was comprised of foliar application of NAA (1\%) viz. $T_{0}$ (control), $T_{1}$ (One spray of NAA), $\mathrm{T}_{2}$ (Two sprays of NAA), $\mathrm{T}_{3}$ (Three sprays of NAA), $\mathrm{T}_{4}$ (Four sprays of NAA). The first foliar spray was applied at 45 days after sowing (DAS) and later on it was continued with 15 days interval with skilled labour by hand pump sprayer. The experiment was laid out in randomized complete block design and each treatment was replicated three times. Data recorded on growth, chlorophyll contents, yield and yield components showed a significant increase with the application of NAA. Furthermore, earliness index, mean maturity date and production rate index were also influenced with foliar application of NAA. On the basis of growth and yield parameters it can be concluded that four spray of NAA (1\%) can be applied commercially under field conditions.
\end{abstract}

Key words: Foliar spray. Growth regulator. NAA. Gossypium hirsutum L. Growth and yield.

\section{Resumo}

Reguladores de crescimento de plantas como ácido naftaleno acético (NAA) afetam positivamente o crescimento e o rendimento das plantas cultivadas. Um experimento foi conduzido para verificar a aplicação foliar de NAA nos componentes de crescimento e rendimento da variedade de algodão Bt.121 sob condições de campo em área de pesquisa do Instituto Cholistan de Estudos do Deserto (CIDS), Islamia University of Bahawalpur, Paquistão. O experimento foi composto de aplicação foliar de NAA (1\%) viz. T0 (controle), $\mathrm{T}_{1}$ (uma pulverização de NAA), $\mathrm{T}_{2}$ (duas pulverizações de NAA), $\mathrm{T}_{3}$ (três pulverizações de NAA), $T_{4}$ (quatro pulverizações de NAA). A primeira pulverização foliar foi aplicada aos 45 dias após a semeadura (DAS) e posteriormente a cada 15 dias de intervalo com pulverizador

\footnotetext{
${ }^{1}$ Student, Cholistan Institute of Desert studies, The Islamia University of Bahawalpur, Pakistan. E-mail: shazia_0509@yahoo.com

2 Professor, University College of Agriculture and Environmental Sciences, The Islamia University of Bahawalpur, Pakistan. E-mail: rmiqbal.iub@gmail.com

3 Assistant Professor, Department of Environmental Sciences, COMSATS Institute of Information Technology, Vehari, 61100 Pakistan. E-mail: akramcp@gmail.com

${ }^{4}$ Student, Department of Plant Breeding and Genetics, Faculty of Agricultural Sciences and Technology, Bahauddin Zakariya University, Multan Pakistan. E-mail: usf301@yahoo.com

5 Assistant Professor, Department of Forestry, Range and Wildlife Management, The Islamia University of Bahawalpur, Pakistan. E-mail: rafay@iub.edu.pk

* Author for correspondence
} 
manual. O experimento foi desenvolvido em delineamento em blocos ao acaso e com três repetições. Os dados registrados sobre o crescimento, os teores de clorofila, os rendimentos e os componentes do rendimento mostraram aumento significativo com a aplicação de NAA. Além disso, o índice de precocidade, a maturidade média e a taxa de produção também foram influenciados pela aplicação foliar de NAA. Com base nos parâmetros de crescimento e rendimento, pode-se concluir que quatro pulverizações de NAA (1\%) podem ser aplicadas comercialmente em condições de campo.

Palavras-chave: Pulverização foliar. Regulador de crescimento. NAA. Gossypium hirsutum L. Crescimento e rendimento.

\section{Introduction}

Cotton (Gossypium hirsutum L.) is subtropical, perennial plant belong to family Malvaceae, with 50 wild and cultivated species. It is one of the most important Kharif season cash crop, cotton occupies a significant place primarily towards agrarian economy of south western districts. Seeds produced by cotton plant used for a multiproduct base like hulls oil, lint and food for animal as well as in textile manufacturing (ARAGAO et al., 2005). Pakistan ranked $4^{\text {th }}$ in cotton production but its yield is low raked at $10^{\text {th }}$ position due to high prices of agricultural inputs (pesticides, fertilizers, etc.), higher intensity of insect and pest attacks, deficiency of water for irrigation, lack of advanced technologies and awareness, adulteration in pesticides and agro-professionalism (NEWS, 2009). Cotton is important for national economy because important fibre crop of Pakistan contributing raw materials to the textile industry and major role in earning foreign exchange. During July-March 2014-15, textile industry fetched foreign exchange of US\$ 10.22 billion (ANONYMOUS, 2014).

The cotton crop production accounts for $1.5 \%$ in Gross Domestic Product (GDP) and 7.1\% in agriculture value addition. Cotton (Gossypium hirsutum L.) is the queen of fibre and leading fibre crop of the world. In Pakistan it is grown over an area of 2961 thousand hectares with a production of 13983 thousand bales and average yield of 802 $\mathrm{kg}$ per hectare (ANONYMOUS, 2014). Bt. cotton is a type of cotton and developed through the transport of a gene from a soil bacterium, Bacillus thuringensis $(\mathrm{Bt})$ by the production of cry protein, which is toxic for insects causing its death by disruption of its digestion process when they feed on plant. In 2009-2010, 70\% of cotton crop planted was Bt and cultivation of Bt transgenic crop reduced the pesticide usage (CARROLL, 2009).

Plant growth regulators are also called plant hormones are the chemicals that are artificially synthesized having similar function as phytohormones. Plant hormones are not nutrients but chemicals that in small amount promote and influence the growth, development and differentiation of cells and tissues (GÜLLÜOĞLU, 2004). Growth regulators can improve the physiological efficiency including photosynthetic ability and can enhance effective partitioning of accumulates from source to sink in the field crops, thus considered as important component of cotton growth management to provide higher seed cotton yields (COPUR et al., 2010).

Application of NAA has good management effect on growth and yield of field crops by increasing fruit setting ratio and fruit dropping (RAOOFI et al., 2014). NAA positively affects the plant growth and improves the maturity of cotton (ABRO, 2004). In comparison with other natural auxin, NAA enhanced the weight and fiber elongation by hindering the secondary cell wall cellulose synthesis (SINGH, 2009). The objective of this study was to investigate the effect of foliar spray of different concentrations of NAA on growth and yield of cotton.

\section{Materials and Methods}

A field experiment was conducted to investigate the effect of foliar application of NAA on growth and yield of cotton crop at Cholistan Institute of 
Desert Studies (CIDS), Baghdad-ul-Jadeed Campus, The Islamia University of Bahawalpur, Pakistan (longitude $=71^{\circ}-41^{\prime} 0^{\prime \prime}$ E, latitude $=29^{\circ}-24^{\prime} 0^{\prime \prime}$ $\mathrm{N}$ and altitude $=116 \mathrm{~m}$ ) under irrigated conditions in the cotton-growing season during 2010-11. The experiment was laid out in Randomized Complete Block Design and replicated three times.

A cotton variety of Bt-121 was planted by drilling method at $75 \mathrm{~cm}$ apart rows, while plant to plant distance was maintained of $30 \mathrm{~cm}$ by thinning just before the first irrigation and net plot size was plot measuring $36.45 \mathrm{~m}^{2}$. Fertilizer i.e. $130 \mathrm{~N}, 60$ $\mathrm{P}_{2} \mathrm{O}_{5}$ and $50 \mathrm{~K}_{2} \mathrm{O} \mathrm{kg}$ per hectare was applied in the form of urea, diamonium phosphate and sulphate of potash. All other agronomic practices were kept uniform for all the treatments.

The experiment was comprised of foliar spray of NAA applied at the rate of $1 \%$ with the treatments as $\mathrm{T}_{0}$ (control), $\mathrm{T}_{1}$ (one spray of NAA), $\mathrm{T}_{2}$ (two sprays of NAA), $T_{3}$ (three sprays of NAA), $T_{4}$ (four sprays of NAA). Phytofix (Naphthalene acetic acid $4.5 \%$ ) was applied with the help of skilled labour by hand pump sprayer. The solution (1\%) of NAA was prepared by dissolving $0.045 \mathrm{~g}$ in 100 liter water. The first spray was done at 45 days after sowing (DAS) and later on was applied at 15 days intervals. The spraying was done with a hand sprayer and first irrigation was applied at 35 DAS while the subsequent irrigations were applied according to the need of crop. All the agronomic practices were carried out uniformly as and when required.

The observations were recorded by randomly selection of four plants from each plot and tagged as A, B, C and D respectively, for recording various parameters during the course of study. Plant height was measured with the help of scale from the ground surface to the plant terminal. Number of leaves per plant were recorded by counting the total number of leaves of four taged plants in each plot and then average was calculated. The numbers of nodes present on the main stem of four tagged plants were counted and average was worked out. Leaf area of four taged plants in a plot was determined by the leaf area meter at different growth stages of crop. Chlorophyll contents (SPAD-502 value) in plant leaf were estimated by chlorophyll meter. To calculate the total number of seeds per boll, ten open bolls were picked from each plot in all treatments and seeds were recorded cautiously. For measuring the weight of seed cotton, ten open bolls picked from each net plot and then separated their locules, in all treatments and weighed seed cotton and locules was determined with the help of digital balance. Seed cotton yield was determined on plot basis. Earliness index was calculated with the help of following formula as proposed by Singh (2003).

$$
\text { Earliness Index }(\%)=\frac{\text { Weight of seed cotton from first pick }}{\text { Total seed cotton weight from all picks }}
$$

Mean maturity date (MMD) in cotton was calculated by the formula as proposed by Christidis and Harrison (1955).

Mean Maturity Date $(\mathrm{MMD})=\frac{\left(\mathrm{W}_{1} \times \mathrm{H}_{1}\right)+\left(\mathrm{W}_{2} \times \mathrm{H}_{2}\right)+\ldots \ldots \ldots+(\mathrm{Wn} \times \mathrm{Hn})}{\mathrm{W}_{1}+\mathrm{W}_{2}+\ldots \ldots . . . \mathrm{Wn}}$

Where $\mathrm{W}=$ weight of seed cotton, $\mathrm{H}=$ number of days from planting to harvest, $1,2 \ldots n=$ consecutive periodic harvest number.

Saleem et al. (2010) calculated that production rate index was calculated from total seed cotton weight divided by the mean maturity date.

Production Rate Index $(\mathrm{g} /$ day $)=\frac{\text { Total seed cotton weight }(\mathrm{g})}{\text { Mean maturity date }(\text { day })}$

Statistical analysis: Data collected during were statistically analyzed using Fisher's analysis of variance technique (ANOVA) and significant means were separated using least significant difference test (LSD) at 5\% probability level (STEEL et al., 1997). Regression and correlation analysis was performed using MS Excel program against different variables. 


\section{Results and Discussion}

Results regarding plant height in all the treatments continued to increase from 45 DAS towards the final harvest. At 54 DAS to onward highest plant height was recorded in $\mathrm{T}_{4}$ treatment (four spray of NAA) and lowest was found in control treatment where no NAA was applied (Figure 1). Abro et al. (2004) also found similar beneficial effect of NAA on plant height, plant height, number of fruiting branches and yield in cotton. Number of leaves in all the treatments continued to increase up to 90 DAS and then gradually declines, however, it increased slightly at 108 DAS. At 54 DAS highest number of leaves per plant was recorded in $\mathrm{T}_{4}$ treatment which is statistically at par $(\mathrm{p}>0.05)$ with the $\mathrm{T}_{3}$ treatment and lowest was recorded in control treatment $\left(\mathrm{T}_{0}\right)$. At 63 DAS to onward maximum number of leaves per plant was found in $\mathrm{T}_{4}$ treatment which differ significantly $(\mathrm{p}<0.05)$ from control treatment (Figure 2). Similar observation was recorded by Revanappa (1993) that the effectiveness of NAA in increasing growth was mainly due to increase in cell division, cell differentiation and cell expansion which enhance the growth of plant.

Number of nodes per plant in all the treatments continued to increase from 45 DAS towards the final harvest. At $63 \mathrm{DAS}$, highest number of nodes per plant was recorded in $\mathrm{T}_{4}$ which is statistically at par ( $p>0.05$ ) with $\mathrm{T}_{3}$ treatment and lowest was recorded in control treatment. Number of nodes per plant at 117 DAS also showed statistically significant difference $(p<0.01)$ among different treatments (Figure 3). Norton et al. (2005) also found a positive effect of foliar application of plant growth regulators on number nodes per plant in cotton. Leaf area per plant in all the treatments continued to increase from 45 DAS to 99 DAS and then gradually declined towards the final harvest. From 54 DAS to onward, leaf area differs significantly $(\mathrm{p}<0.01)$ from each other under different sprays of NAA (Figure 4). Similar results were found by Mir et al. (2010) that foliar applications of growth regulators significantly affect the leaf area per plant.

Figure 1. Effect of different foliar application of NAA on plant height $(\mathrm{cm})$ in cotton.

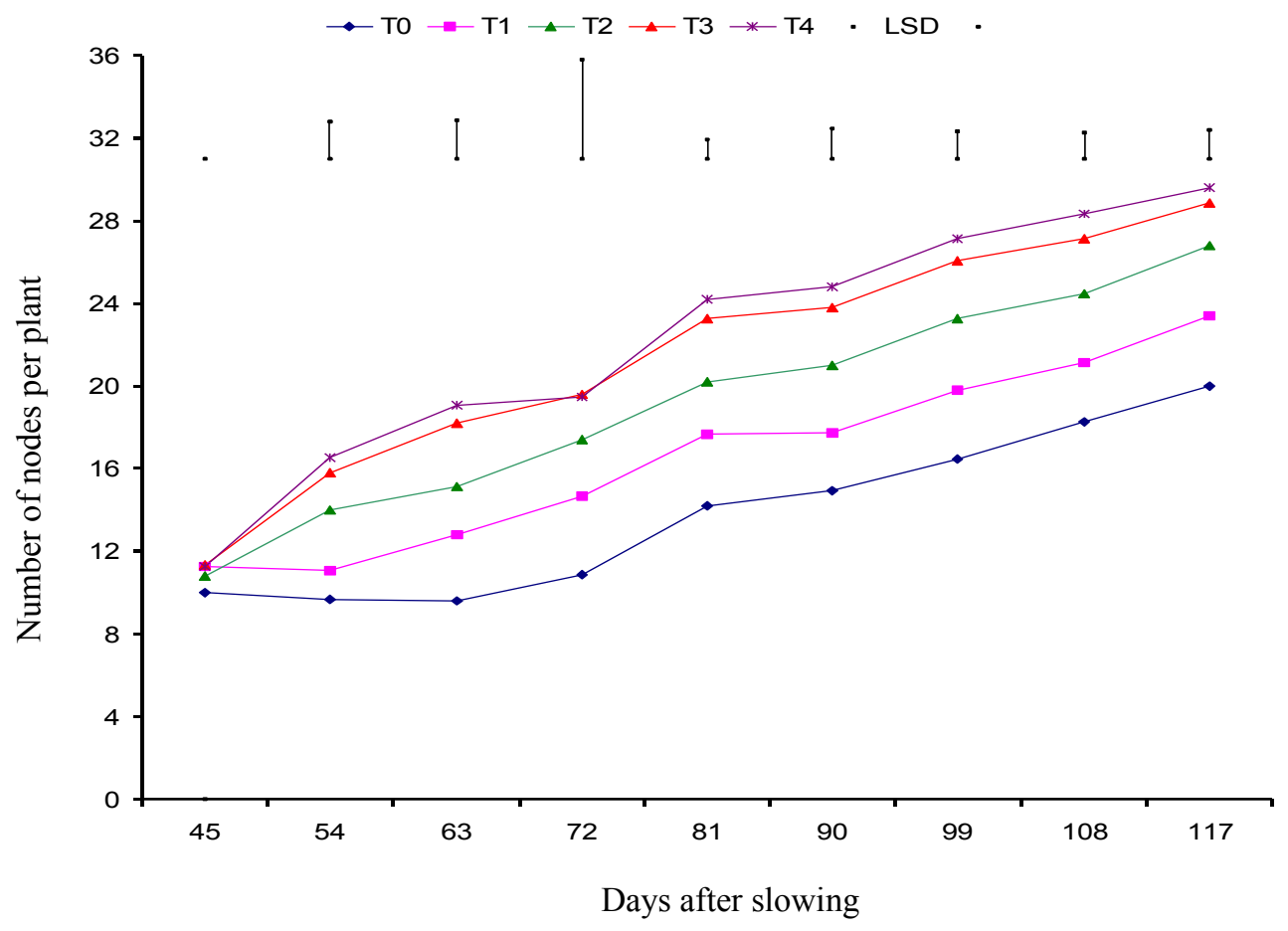


Figure 2. Effect of different spray of NAA on number of leaves per plant in cotton.

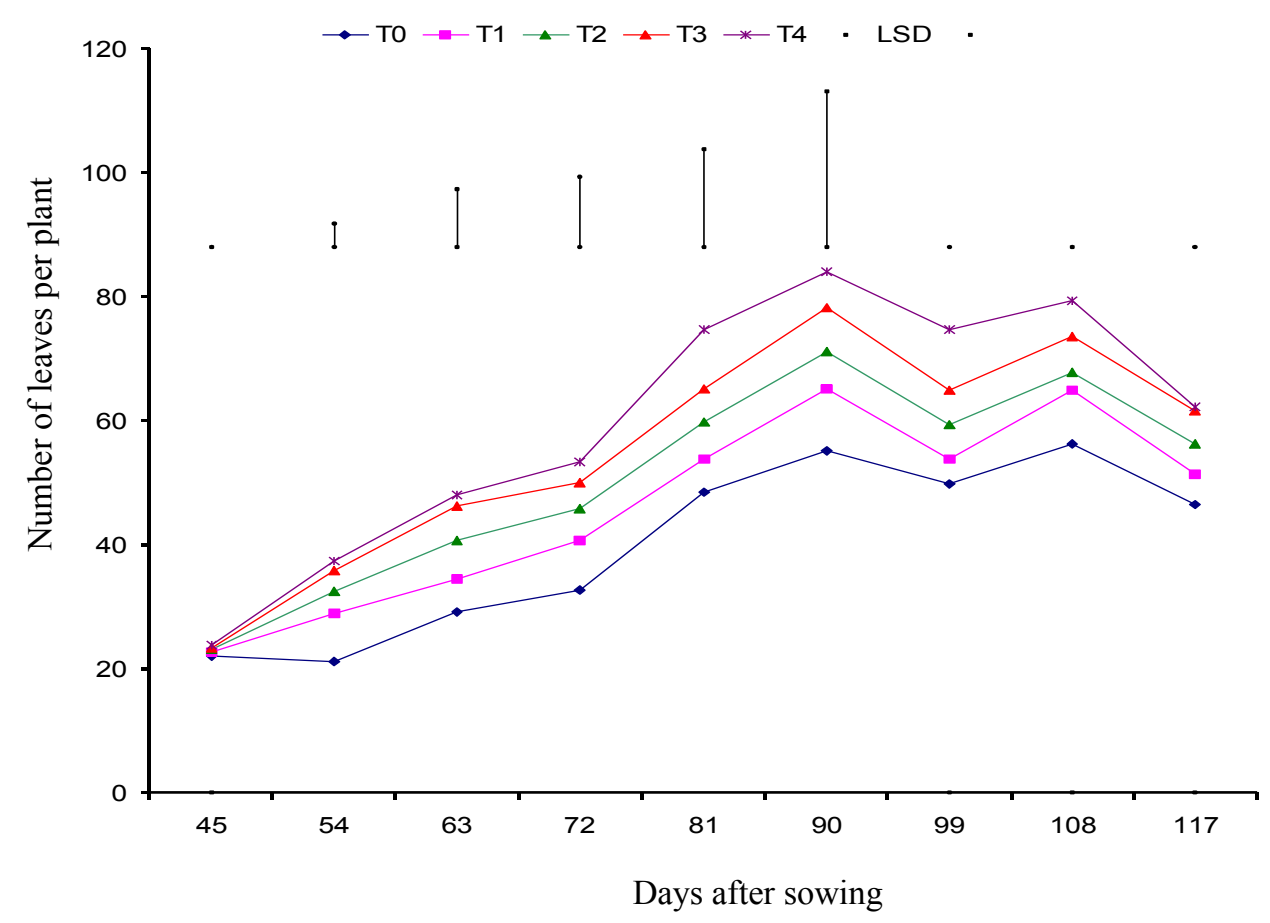

$\mathrm{T}_{0}$ : Control (no application) $\mathrm{T}_{1}$ : One spray of NAA $(1 \%) \mathrm{T}_{2}$ : Two sprays of NAA $(1 \%)$

$\mathrm{T}_{3}$ : Three sprays of NAA (1\%) $\mathrm{T}_{4}$ : Four sprays of NAA (1\%) LSD: Least significant difference.

Figure 3. Effect of different sprays of NAA on number of nodes per plant in cotton.

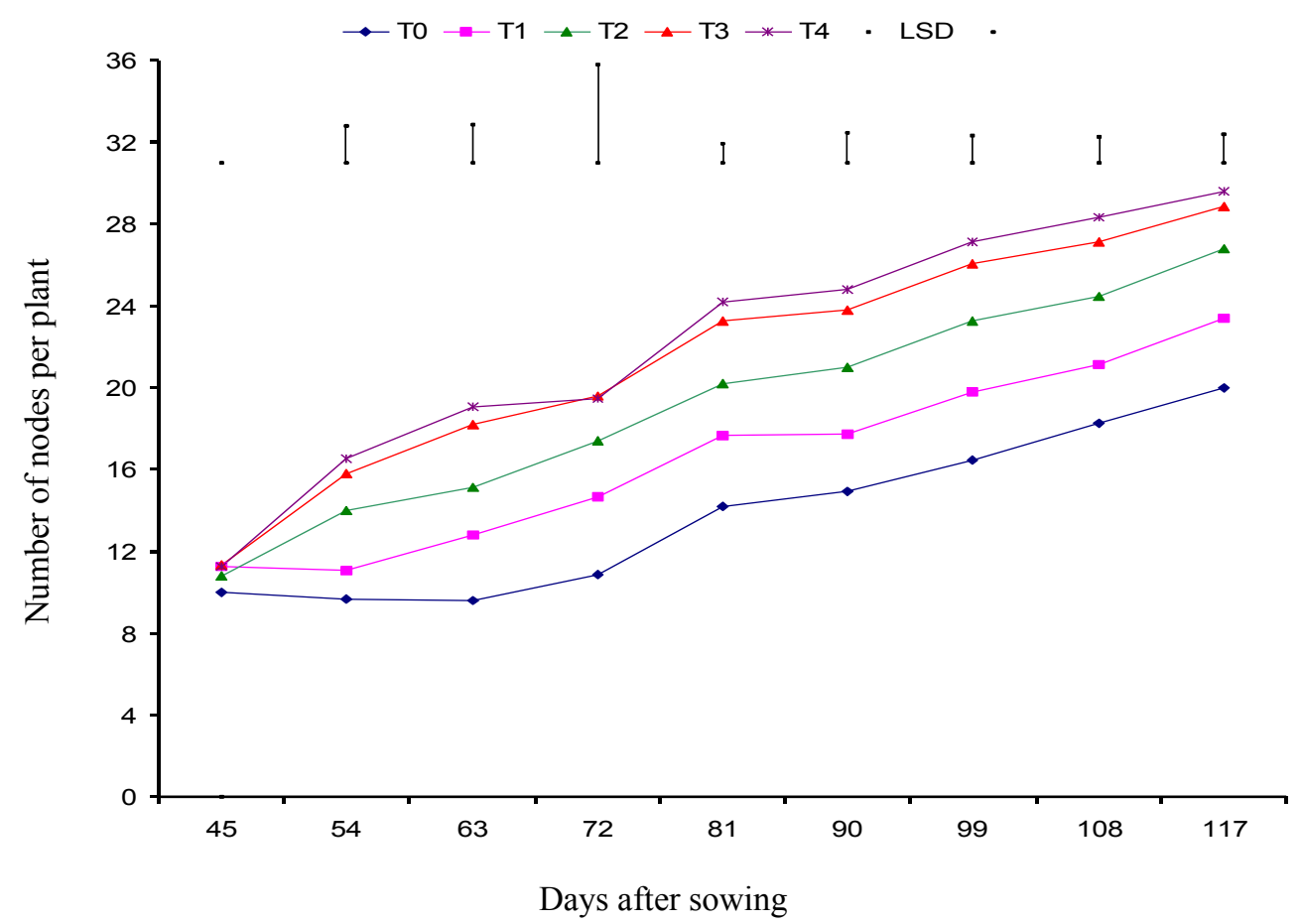


Figure 4. Effect of different sprays of NAA on leaf area $\left(\mathrm{cm}^{2}\right)$ per plant in cotton.

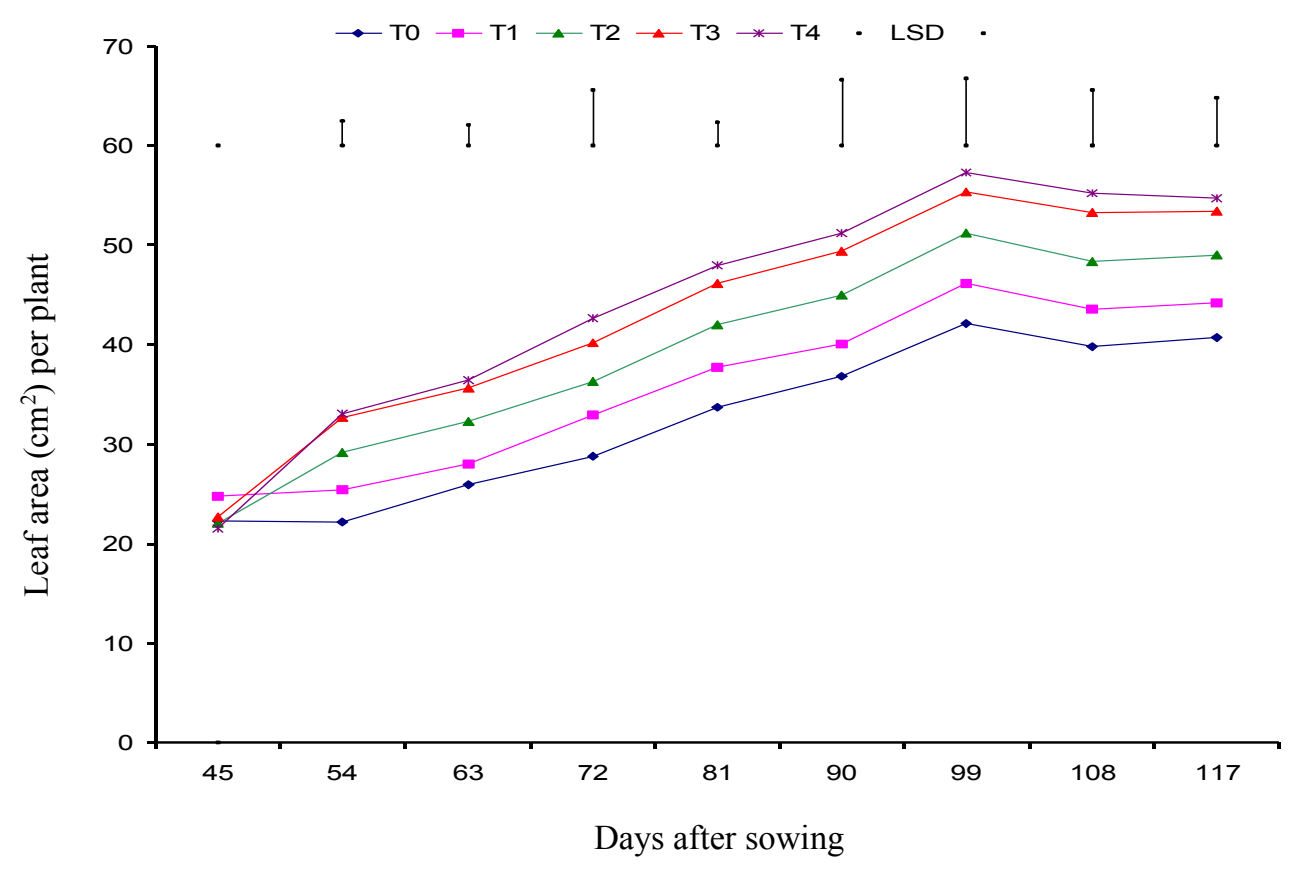

$\mathrm{T}_{0}$ : Control (no application) $\mathrm{T}_{1}$ : One spray of NAA (1\%) $\mathrm{T}_{2}$ : Two sprays of NAA $(1 \%)$

$\mathrm{T}_{3}$ : Three sprays of NAA (1\%) $\mathrm{T}_{4}$ : Four sprays of NAA (1\%) LSD: Least significant difference.

Chlorophyll contents as influenced by different level of NAA increased progressively from 54 to 90 DAS and then decreased towards the final harvest. At 54 and 63 DAS the chlorophyll contents differ significantly $(p<0.05)$ under different sprays of NAA. At 117 DAS maximum chlorophyll content was recorded in $\mathrm{T}_{4}$ and lowest value was recorded in control, furthermore; $\mathrm{T}_{4}$ treatment was statistically at par $(\mathrm{p}>0.05)$ with $\mathrm{T}_{3}$ treatment and $\mathrm{T}_{1}$ and $\mathrm{T}_{2}$ treatments were also at par $(p>0.05)$ with each other (Figure 5). Application of growth regulators causes variation in chlorophyll contents present in plant by increasing the chlorophyll synthesis and reduction in chlorophyll degradation. Senthil et al. (2003) investigated the effects of NAA at $40 \mathrm{ppm}$ and IAA at $100 \mathrm{ppm}$ supplied as foliar spray at 35 and 60 DAS on some biochemical and physiological aspects including total chlorophyll and soluble protein of soybean plant. Application of NAA was more economical as compared to control by recording maximum yield and yield components including photosynthesis (KIRAN KUMAR et al., 2002).

Number of bolls per plant in all the treatments also continued to increase from 62 DAS towards the final harvest. Maximum number of bolls per plant was recorded when four spray of NAA was applied (highest dose) which is followed by $\mathrm{T}_{3}$ treatment and minimum was recorded in control treatment (Figure 6). Highest weight of seed cotton per open boll (3.46) were recorded with four sprays of NAA (highest dose) which is followed by treatment $\mathrm{T}_{3}(3.26)$ and $\mathrm{T}_{2}$ (3.18) and $\mathrm{T}_{1}(2.94)$ and lowest was recorded in control (2.63) where no NAA was applied. There is $23.98 \%$ more weight of seed cotton per open boll in $\mathrm{T}_{4}$ treatment than $\mathrm{T}_{0}$ (control) was recorded (Table 1). Russell (2006) found that increase in yield is also due to higher number of leaves that provides the photo assimilates and as a result of delayed senescence of leaves for an extended period. 
Figure 5. Effect of different sprays of NAA on chlorophyll contents (SPAD-502 values) in cotton.

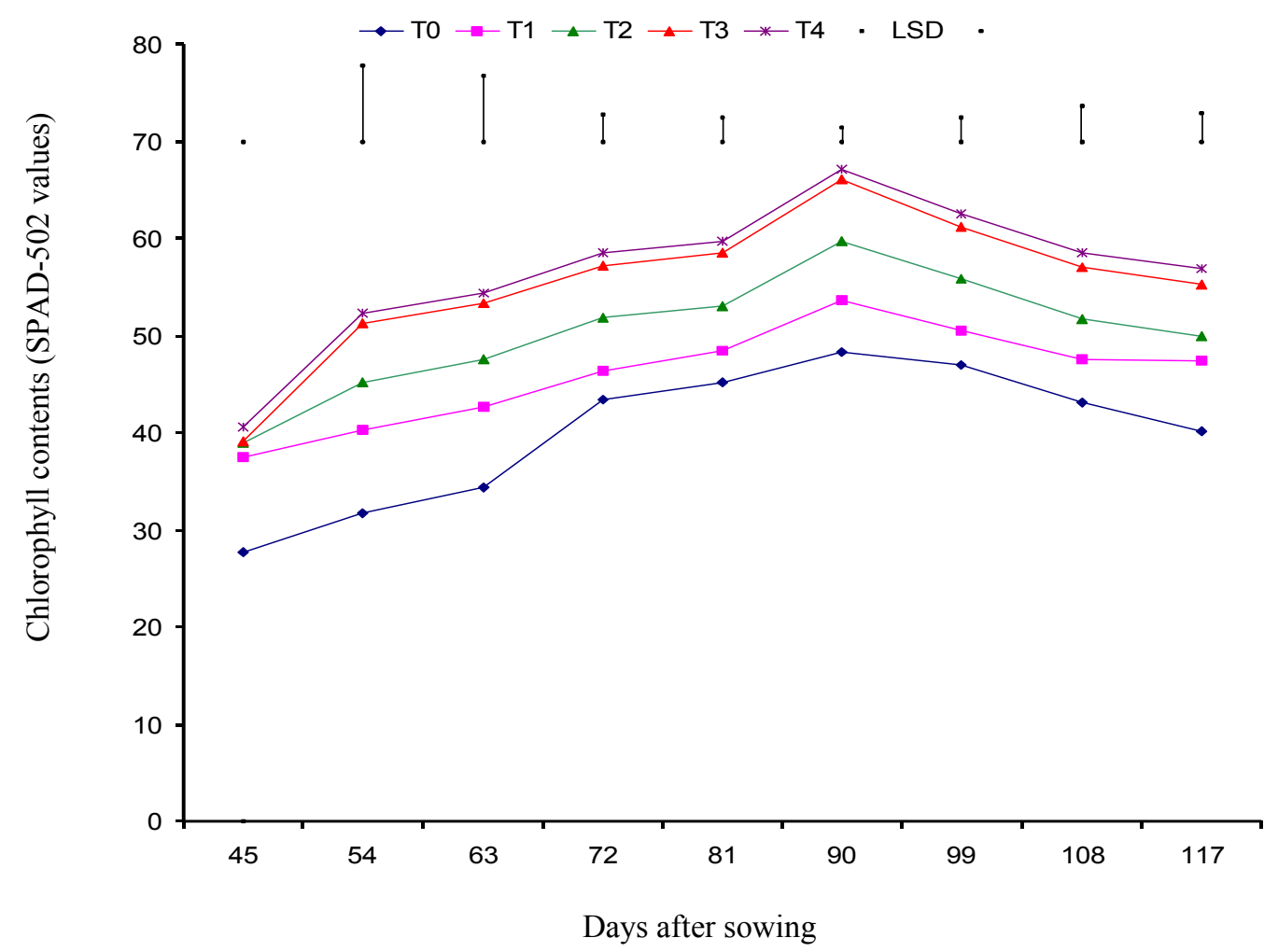

Figure 6. Effect of different sprays of NAA on number of bolls per plant in cotton.

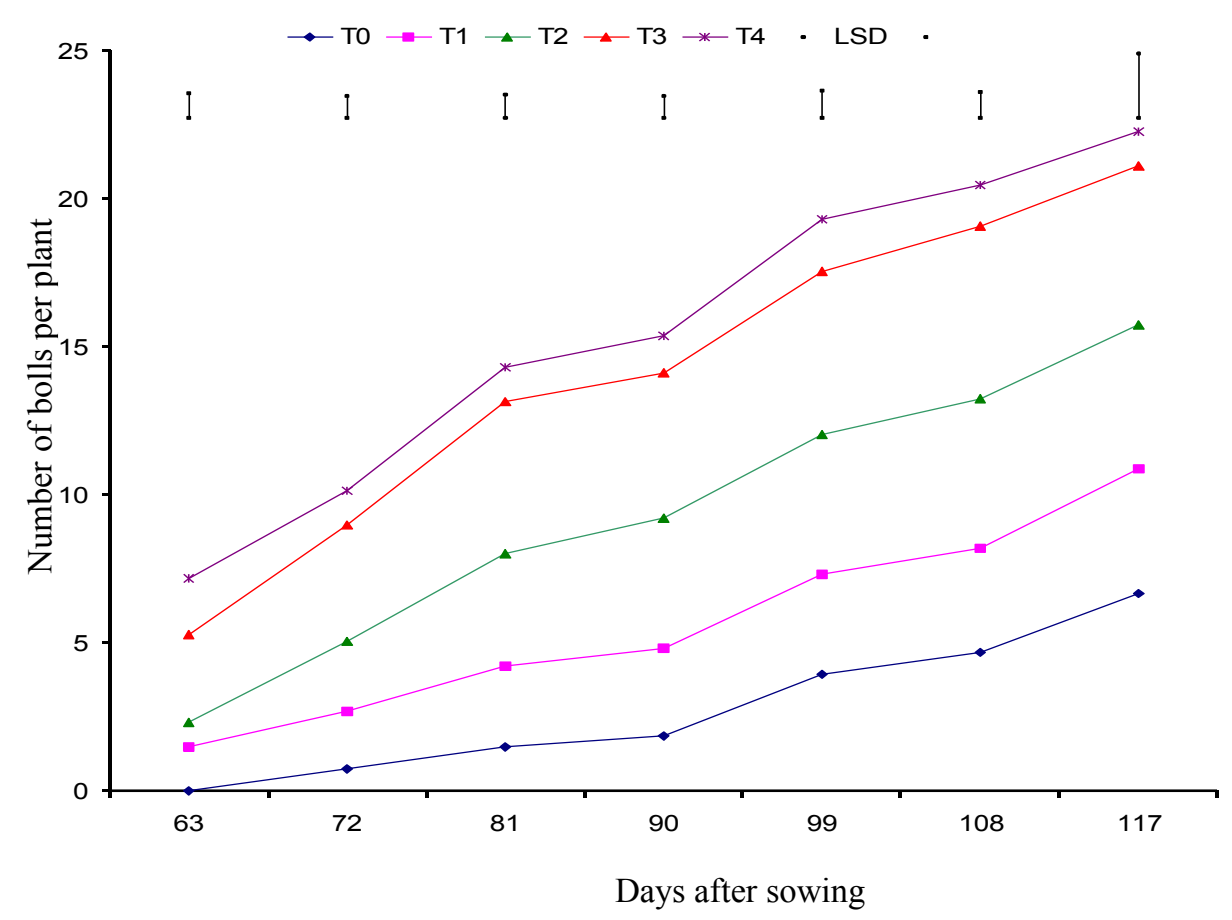

$\mathrm{T}_{0}$ : Control (no application) $\mathrm{T}_{1}$ : One spray of NAA (1\%) $\mathrm{T}_{2}$ : Two sprays of NAA (1\%)

$\mathrm{T}_{3}$ : Three sprays of NAA (1\%) $\mathrm{T}_{4}$ : Four sprays of NAA (1\%) LSD: Least significant difference. 
Highest weight of locules per open boll (1.73) was recorded with four sprays of NAA while the lowest was recorded in control (1.06) where no NAA was applied. Treatment $T_{2}$ and $T_{1}$ showed statistically at par $(p>0.05)$ results with respect to weight of locules per open boll. Furthermore, it was observed that $\mathrm{T}_{4}$ treatment has $38.72 \%$ more weight of locules per open boll than control treatment (Table 1). Maximum number of cotton seed per open boll was recorded in $\mathrm{T}_{4}$ treatment which is statistically at par ( $>0.05)$ with $\mathrm{T}_{3}$ and minimum was in control treatment. Treatments $\mathrm{T}_{0}, \mathrm{~T}_{1}$ are $\mathrm{T}_{2}$ were statistically at par ( $>0.05)$ with each other (Table 1). In study on Brinjil, Patil (2005) also reported that higher fruit weight and seed yield per plant was recorded with the application of NAA. Seed cotton yield also increased with the application of NAA and four sprays of NAA produced maximum seed cotton yield (2574) which is followed by $\mathrm{T}_{3}(2516), \mathrm{T}_{2}$ (2461) and $T_{1}$ treatment (2369) respectively. There is $13.72 \%$ more yield in $\mathrm{T}_{4}$ treatment than $\mathrm{T}_{0}$ (Table 1). Similar results were observed by Gencsoylu, (2009) that foliar application of growth regulators significantly increased number of bolls per plant of cotton crop. Hallikeri et al. (2002) also stated that application of NAA with micronutrient significantly increased the seed cotton yield.

Results of present experiment showed that the maximum earliness index (68.20) was found in $T_{4}$ treatment (four spray of NAA) was applied and minimum (66.37) in $\mathrm{T}_{0}$ treatment (control) (Table 1). Application of synthetic auxin like NAA may cause rapid cell division and cell elongation in the growing part of plants due to efficient translocation and utilization of photosynthetic metabolic product and also by enhancing the rate of photosynthesis (NATEH et al., 2005). Cothren (1999) in a study also investigated that plant growth regulators increased productivity and earliness by flowering, assimilation partitioning and yield enhancement.

Table 1. Effect of foliar application of NAA on earliness index, mean maturity date and production rate index, weight of seed cotton per boll, weight of locules per boll, number of cotton seeds per open boll and seed cotton yield.

\begin{tabular}{cccccccc}
\hline Treatments & $\begin{array}{c}\text { Weight of } \\
\text { seed cotton } \\
\text { per boll }(\mathrm{g})\end{array}$ & $\begin{array}{c}\text { Weight of } \\
\text { locules } \\
\text { per boll }(\mathrm{g})\end{array}$ & $\begin{array}{c}\text { Number of } \\
\text { cotton seed } \\
\text { per open boll }\end{array}$ & $\begin{array}{c}\text { Seed cotton } \\
\text { yield } \\
(\mathrm{Kg} / \mathrm{ha})\end{array}$ & $\begin{array}{c}\text { Earliness } \\
\text { index }(\%)\end{array}$ & $\begin{array}{c}\text { Mean } \\
\text { maturity } \\
\text { date }(\text { days })\end{array}$ & $\begin{array}{c}\text { Production } \\
\text { rate index } \\
(\mathrm{g} / \text { day })\end{array}$ \\
\hline $\mathrm{T}_{\mathrm{o}}$ & $2.63 \mathrm{c}$ & $1.06 \mathrm{~d}$ & $15.2 \mathrm{~d}$ & $2220 \mathrm{a}$ & $66.37 \mathrm{~b}$ & $160.10 \mathrm{a}$ & $25.78 \mathrm{c}$ \\
$\mathrm{T}_{\mathrm{I}}$ & $2.94 \mathrm{bc}$ & $1.26 \mathrm{c}$ & $17.63 \mathrm{c}$ & $2369 \mathrm{ab}$ & $65.85 \mathrm{~b}$ & $160.20 \mathrm{a}$ & $27.49 \mathrm{bc}$ \\
$\mathrm{T}_{2}$ & $3.18 \mathrm{ab}$ & $1.40 \mathrm{c}$ & $19.17 \mathrm{~b}$ & $2461 \mathrm{ab}$ & $66.31 \mathrm{~b}$ & $160.10 \mathrm{a}$ & $28.57 \mathrm{ab}$ \\
$\mathrm{T}_{3}$ & $3.26 \mathrm{ab}$ & $1.56 \mathrm{~b}$ & $21.73 \mathrm{a}$ & $2516 \mathrm{bc}$ & $66.53 \mathrm{~b}$ & $160.00 \mathrm{ab}$ & $29.23 \mathrm{ab}$ \\
$\mathrm{T}_{4}$ & $3.46 \mathrm{a}$ & $1.73 \mathrm{a}$ & $22.6 \mathrm{a}$ & $2574 \mathrm{c}$ & $68.20 \mathrm{a}$ & $159.70 \mathrm{~b}$ & $29.95 \mathrm{a}$ \\
$\mathrm{LSD}$ at 5\% & 0.347 & 0.146 & 1.024 & 0.326 & 1.73 & 0.36 & 02.07 \\
\hline
\end{tabular}

$\mathrm{T}_{0}$ : Control (no application) $\mathrm{T}_{1}$ : One spray of NAA (1\%) $\mathrm{T}_{2}$ : Two sprays of NAA (1\%)

$\mathrm{T}_{3}$ : Three sprays of NAA $(1 \%) \mathrm{T}_{4}$ : Four sprays of NAA $(1 \%)$.

Mean maturity date (MMD) was maximum (160.2) in $T_{1}$ treatment and minimum (159.7) in $\mathrm{T}_{4}$ treatment. Treatment $\mathrm{T}_{2}$ has MMD 160.2, $\mathrm{T}_{3}$ has $160, \mathrm{~T}_{4}$ has 159.7 and in $\mathrm{T}_{0}$ MMD was 160.1 (Table 1). Tamas (1972) stated that yield of cotton seed influenced by the application of NAA and it was mainly due to stimulating effects of auxin on the photosynthetic capacity of chloroplast. Production rate index in treatment $T_{1}$ has $27.49, T_{2}$ has 28.57 and $\mathrm{T}_{3}$ has 29.23, maximum (29.95) in $\mathrm{T}_{4}$ treatment and minimum (25.78) in $\mathrm{T}_{0}$ (control) where NAA was not applied (Table 1). Richmond and Ray (1966) also found that MMD provided a more accurate measurement of earliness and NAA treatments show significant increase in earliness index and production rate index as compared to control treatment. 


\section{Correlations and regression analysis}

The correlation analysis showed a positive and linear association between plant height and SCY ( $\mathrm{r}$ $=0.99 ; \mathrm{p}<0.05)$. Positive and linear correlation ( $\mathrm{r}=$ 0.99) was observed between number of leaves per plant and SCY. Regression analysis also indicate the dependence of SCY on number of leaves per plant $\left(\mathrm{R}^{2}=0.97 ; \mathrm{p}<0.05\right)$. Regression and correlation model shows the positive and linear relationship between leaf area and SCY $\left(\mathrm{R}^{2}=0.96 ; \mathrm{r}=0.98\right)$ as shown in table 2. The association between number of cotton seed per open boll and SCY is supported by regression model which showed the dependence of SCY on number of cotton seed per open boll $\left(\mathrm{R}^{2}=0.96 ; \mathrm{p}<0.05\right)$. Regression analysis model indicate the positive and linear association between chlorophyll content and SCY $\left(\mathrm{R}^{2}=0.98\right.$; $\mathrm{p}<0.05$ ) (Table 2). Sawan and Sakr (1998) also investigated the effect of the treatments of NAA on cotton growth, yield and yield components. The application of NAA increased the number of opened bolls, boll weight which positively contribute towards increasing in seed cotton yield.

Table 2. Regression equation, linear regression coefficients $\left(\mathrm{R}^{2}\right)$ and correlation coefficient between seed cotton yield and different parameters of cotton.

\begin{tabular}{lccc}
\hline Characters & Regression equation & $\begin{array}{c}\text { Linear regression } \\
\text { coefficient }\left(\mathrm{R}^{2}\right)\end{array}$ & $\begin{array}{c}\text { Correlation } \\
\text { coefficient }(\mathrm{r})\end{array}$ \\
\hline SCY vs plant height & $\mathrm{y}=32.108 \mathrm{x}+684.57$ & 0.97 & 0.99 \\
SCY vs leaf area per plant & $\mathrm{y}=27.24 \mathrm{x}+1363.6$ & 0.96 & 0.98 \\
SCY vs Chlorophyll contents & $\mathrm{y}=19.933 \mathrm{x}+1437.1$ & 0.98 & 0.99 \\
SCY vs number of bolls per plant & $\mathrm{y}=24.524 \mathrm{x}+2195.4$ & 0.93 & 0.97 \\
SCY vs number of cotton seed per open boll & $\mathrm{y}=45.075 \mathrm{x}+1560.2$ & 0.96 & 0.98 \\
SCY vs weight of seed cotton per open boll & $\mathrm{y}=432.01 \mathrm{x}+1092$ & 0.99 & 0.99 \\
SCY vs number of leaves per plant & $\mathrm{y}=17.771 \mathrm{x}+1532.5$ & 0.97 & 0.99 \\
\hline
\end{tabular}

$\mathrm{SCY}=$ Seed cotton yield vs $=$ versus.

\section{Conclusions}

Data recorded on growth, chlorophyll contents, yield and yield components showed a significant increase with the application of NAA. Furthermore, earliness index, mean maturity date and production rate index were also influenced with foliar application of NAA. On the basis of growth and yield parameters it can be concluded that four spray of NAA (1\%) can be applied commercially under field conditions.

\section{References}

ABRO, G. H.; SYED T. S.; UNAR, M. A.; ZHANG, M. $\mathrm{S}$. Effect of a plant growth regulator and micronutrients on insect pest infestation and yield components of cotton. Journal of Entomology, Academic Journals Inc., v. 1, n. 1, p. 12-16, 2004.
ANONYMOUS. Economic Survey of Pakistan. (201415). Finance Division, Economic Advisory Wings Islamabad, 2014. p. 26-27.

ARAGAO, F. J. L.; VIANNA, G. R.; CARVALHEIRA, S. B. R. C.; RECH, E. L. Germ line genetic transformation in cotton (Gossypium hirsutum L.) by selection of transgenic meristematic cells with a herbicide molecule. Plant Science, California, v. 168, n. 5, p. 1227-1233, 2005.

CARROLL, J. Pakistan annual cotton report: global agricultural information network report. Washington, DC: USDA Foreign Agriculture Service, 2009.

CHRISTIDIS, R. G.; HARRISON, G. J. Cotton growing problems. New York: McGraw-Hill Book Company, 1955. $16 \mathrm{p}$.

COPUR, O.; DEMIREL, U.; KARAKUS, M. Effects of several plant growth regulators on the yield and fiber quality of cotton (Gossypium hirsutum L.). Notulae Botanicae Horti Agrobotanici Cluj-Napoca, Academic Press, v. 38, n. 3, p. 104-110, 2010. 
COTHREN, J. T. Cotton: origin, history, technology and production. In: COTHREN, J. T. (Ed.). Physiology of the cotton plant. New York: John Wiley \& Sons, Inc, 1999. p. 207-268.

GENCSOYLU, I. Effect of plant growth regulators on agronomic characteristics, lint quality, pest and predators in cotton. Journal Plant Growth Regulator, Dordrecht, v. 28, n. 2, p. 147-153, 2009.

GÜLLÜOĞLU, L. Determination of usage of plant growth regulators in soybean (Glycine max L.) farming under Harran plain conditions. University of Harran (Turkey). Journal of the Faculty of Agriculture, Turkish, v. 8, n. 3-4, p. 17-23, 2004.

HALLIKERI, S. S.; HALEMANI, H. L.; KHADI, B. M. Integrated foliar nutrition for yield maximization of rainfed cotton. Karnataka Journal of Agriculture Science, Dharward, v. 15, p. 562-565, 2002.

KIRAN KUMAR, K.; PATIL, B. C.; CHETTI, M. B. Effect of plant growth regulators on biophysical, biochemical parameters and yield of hybrid cotton. Karnataka Journal of Agriculture Science, Dharwad, v. 16, p. 591-594, 2002.

MIR, M. R.; MOBIN, M.; KHAN, N. A.; BHAT, M. A.; LONE, N. A.; BHAT, K. A.; RAZVI, S. M.; WANI, S. A.; WANI, N.; AKHTER, S.; RASHID, S.; MASOODI, N. H.; PAYNE, W. A. Crop Responses to Interaction between plants growth regulators and nutrients. Journal of Phytology, Periodical of Scienceflora Publishers Pvt. Ltd., v. 2, n. 10, p. 9-19, 2010.

NATEH, N.; VYAKARNAHAL, B. S.; GOUDA, M. S.; DESHPANDE, V. K. Influence of growth regulators on growth, seed yield and quality of chilli cv. Byadagi Kaddi. Karnataka Journal of Agriculture Science, Dharward, v. 18, p. 36-38, 2005.

NEWS, A. Pakistan allows Bt. cotton cultivation. Zhejiang, China: Author.2009. Available at: <http:// www.glgroup.com/News/Pakistan-Allows-Bt-CottonCultivation-42810.html $>$. Accessed at: 15 ago. 2015.

NORTON, E. R.; CLARK, L. J.; BORREGO, H.; ELLSWORTH, B. Evaluation of two plant growth regulators from LT Biosyn, Arizona Cotton Reports, 2005. $142 \mathrm{p}$.

PATIL, S. B. Standardization of hybrid seed production techniques in brinjal (Solanum melongena L.). 2005. Ph.D. (Thesis) - University of Agriculture Science, Dharwad.
RAOOFI, M. M.; DEHGHAN, S.; KEIGHOBADI, M.; POODINEH, O. Effect of naphthalene acetic acid in agriculture and the role of increase yield. International Journal of Agriculture and Crop Sciences. Mansoura, v. 7, n. 14, p. 1378-1380, 2014.

REVANAPPA. Response of green chilli (Capsicum annum L.) genotypes to nitrogen levels, plant density and growth regulators. 1993. Ph. D. (Thesis) - University of Agriculture Science, Dharwad.

RICHMOND, T. R.; RAY, L. L. Product-quantity measures of earliness of crop maturity in cotton. Crop Science, Madison, v. 6, n. 3, p. 235-239, 1966.

RUSSELL, L.; NUTI, RYAN, P.; VIATDR, SHAUN, N.; CASTELL, KEITH, L. E.; RANDY, W. Effect of planting date, mepiquat chloride and glyphosate application to glyphosate, resistant cotton. Agronomy Journal, Madison, v. 98, n. 6, p. 1627-1633, 2006.

SALEEM, M. F.; SHAKEEL, A.; BILAL, M. F.; SHAHID, M. Q.; ANJUM. S. A. Effect of different phosphorus levels on earliness and yield of cotton cultivars. Soil and Environment, Faisalabad, v. 29, n. 2, p. 128-135, 2010.

SAWAN, Z. M.; SAKR, R. A. Effect of 1-naphthalene acetic acid concentrations and the number of applications on the yield components, yield and fibre properties of the Egyptian cotton (Gossypium barbadense L.). Agronomie, Les Ulis Cedex, v. 18, n. 4, p. 275-283, 1998.

SENTHIL, A.; PATHMANABAN, G.; SRINIVASAN, P. S. Effect bioregulators on some physiological and biochemical parameters of soybean (Glycine max L.). Legume Research, Karnal, v. 26, n. 1, p. 54-56, 2003.

SINGH, B.; CHEEK, H. D.; HAIGLER, C. H. A synthetic auxin (NAA) suppresses secondary wall cellulose synthesis and enhances elongation in cultured cotton fiber. Plant Cell Reports, Heidelberg, v. 28, n. 7, p. 1023-1032, 2009.

SINGH, S. S. Soil fertility and nutrient management. New Delhi: Kalyani Publishers, v. 38, 2003.

STEEL, R. G. D.; TORRIE, T. H.; DICKEY, D. A. Principles and procedures of statistics. In: __. A biometrical approach. $3^{\text {the }}$. Singapore: Mc $\overline{\text { Graw Hill }}$ Book International Co. Inc. New York,1997. p. 400-428.

TAMAS, I. A.; ATKINS, B. D.; WARE, S. M.; BIDWELL R. G. S. Indole acetic acid stimulation of phosphorylation and bicarbonate fixation by chloroplast preparation in light. Canadian Journal of Botany, Ottawa, v. 50, n. 7, p. 1523-1527, 1972. 